\title{
ANALISIS KADAR MERKURI PADA KOMPONEN EKOSISTEM AKIBAT PETI DI SUNGAI TEBAUNG KABUPATEN KAPUAS HULU
}

Ponti Astika ${ }^{1)}$, Dian Rahayu Jati ${ }^{1)}$, Ulli Kadaria ${ }^{1)}$

1) Program Studi Teknik Lingkungan Jurusan Teknik Sipil Fakultas Teknik Universitas Tanjungpura, Pontianak Email : pontiastika22@gmail.com

\begin{abstract}
ABSTRAK
PETI di Sungai Tebaung Kabupaten Kapuas Hulu telah berlangsung sejak tahun 1999 dengan menggunakan merkuri sebagai amalgaman. Merkuri dapat menyebabkan pencemaran sungai, dapat menganggu ekosistem sungai serta kesehatan manusia. Tujuan dilakukannya penelitian ini adalah menganalisis kadar merkuri pada air permukaan, sedimen, ikan dan tumbuhan di Sungai Tebaung, menganalisis akumulasi merkuri pada rambut manusia yang tinggal di bantaran Sungai Tebaung serta menganalisis persebaran merkuri pada komponen ekosistem di Sungai Tebaung. Pengujian merkuri dilakukan sampel dilakukan dengan meode AAS. Dari hasil penelitian menunjukan konsentrasi merkuri pada air permukaan di hulu sungai sebesar $0,004 \mathrm{mg} / \mathrm{l}$, di tengah sungai $0,0049 \mathrm{mg} / \mathrm{l}$ dan hilir Sungai 0,0063 mg/l ketiga titik sampel melebihi baku mutu menurut PP 82 Tahun 2001 kelas 2 sebesar $0,002 \mathrm{mg} / \mathrm{l}$. Konsentrasi merkuri pada sedimen di hulu sungai sebesar $0,1815 \mathrm{mg} / \mathrm{l}$, tengah sungai $0,0585 \mathrm{mg} / \mathrm{l}$ dan hilir sungai $0,124 \mathrm{mg} / \mathrm{l}$ ketiga titik sampel juga telah melebihi baku mutu yang ditetapkan oleh PP 18 tahun 1999 yaitu $0,1 \mathrm{mg} / \mathrm{l}$. Konsentrasi merkuri pada paku sayur di hulu sungai sebesar $0,0096 \mathrm{mg} / / \mathrm{kg}$, di tengah sungai $0,0124 \mathrm{mg} / \mathrm{kg}$ dan hilir sungai $0,0193 \mathrm{mg} / \mathrm{kg}$ ketiga sampel juga telah melebihi baku mutu SNI 7383-2009 yaitu 0,003 mg/kg. Konsentrasi merkuri pada ikan di hulu dan di tengah sungai sebesar $<0,004 \mathrm{mg} / \mathrm{kg}$, di hilir sungai $0,0047 \mathrm{mg} / \mathrm{kg}$ ketiga sampel dibawah baku mutu yang ditetapkan WHO 2005 yaitu 0,5 mg.kg. Akumulasi merkuri pada sampel rambut manusia di Desa Semangut sebesar 0,05 mg/kg, Desa Sebilit 0,067 mg/kg dan Desa Nanga Suruk sebesar 0,813 mg/kg ketiga sampel masih dibawah baku mutu yang ditetapkan oleh WHO 1990 yaitu $1 \mathrm{mg} / \mathrm{kg}$.
\end{abstract}

Kata Kunci : merkuri, sungai, ekosistem, persebaran.

\begin{abstract}
The CRATE on the river Tebaung Regency Kapuas Hulu has lasted since 1999 by using mercury as amalgaman. Mercury can cause contamination of the River, can interfere with river ecosystem and human health. The purpose of doing this research is analyzing the levels of mercury in surface water, sediments, fish and plants on the river Tebaung, analyse the accumulation of mercury in the hair of people living on the banks of the river Tebaung as well as analyzing the distribution of mercury on the components of the ecosystem on the river Tebaung. Mercury testing done samples done with meode AAS. From the results of the research showed the concentration of mercury in surface water in the River upstream of $0.004 \mathrm{mg} / \mathrm{l}$, in the midst of the river of $0.0049 \mathrm{mg} / \mathrm{l}$ and downstream River 0.0063 $\mathrm{mg} / \mathrm{l}$ sample point exceed the third raw quality according to PP 822001 class 2 of $0.002 \mathrm{mg} / \mathrm{l}$. concentrations of mercury in sediments in the River upstream of $0.1815 \mathrm{mg} / \mathrm{l}$, the middle of rivers $0.0585 \mathrm{mg} / \mathrm{l}$ and downstream third $0.124 \mathrm{mg} / \mathrm{l}$ sample point has also exceeded the raw quality set by the PP 18 in 1999, IE $0.1 \mathrm{mg} / \mathrm{l}$. concentrations of mercury in the River upstream of vegetable spikes of $0.0096 \mathrm{mg} / \mathrm{kg}$, in the midst of the river of $0.0124 \mathrm{mg} / \mathrm{kg}$ and a lower $0.0193 \mathrm{mg} / \mathrm{kg}$ third sample also has surpassed the raw quality of SNI 7383-2009 i.e. $0.003 \mathrm{mg} / \mathrm{kg}$. Mercury concentrations in fish in the upper reaches of the river and in the middle of $<0.004 \mathrm{mg} / \mathrm{kg}$, in the lower reaches of the river $0.0047 \mathrm{mg} / \mathrm{kg}$ of the sample under the third raw quality that set WHO 2005 i.e. $0.5 \mathrm{mg} . \mathrm{kg}$. The accumulation of mercury in human hair samples in the Semangut Village of $0.05 \mathrm{mg} / \mathrm{kg}$, village Sebilit $0.067 \mathrm{mg} / \mathrm{kg}$ and the village of Nanga Suruk of $0.813 \mathrm{mg} / \mathrm{kg}$ of the sample is still under the third raw quality set by the WORLD HEALTH ORGANIZATION 1990 is $1 \mathrm{mg} / \mathrm{kg}$.
\end{abstract}

Key words: Mercury, river, ecosystems, distribution. 


\section{- Pendahuluan}

Pencemaran merkuri di sungai dapat diakibatkan oleh aktivitas manusia salah satunya pertambangan emas tanpa izin (PETI). Sungai Tebaung merupakan salah satu sungai yang berada di Kabupaten Kapuas Hulu. Kegiatan pertambangan emas tanpa izin (PETI) di Sungai Tebaung telah berlangsung sejak tahun 1999. Kegiatan PETI tersebut dilakukan masyarakat setempat dan warga pendatang dengan jumlah pertambangan pada akhir 2015 sebanyak 53 dan jumlah pertambangan kemungkinan akan bertambah seiring perkembangan di daerah tersebut.

Sungai yang terkontaminasi merkuri dapat menyebabkan merkuri terakumulasi pada mikroorganisme yang hidup di badan air melalui proses metabolisme (Wurdiyanto, 2007). Mikroorganisme yang telah terpapar methyl merkuri dimakan oleh ikan sehingga methyl merkuri terakumulasi dalam jaringan tubuh ikan. Ikan kecil dimakan ikan besar dan akhirnya dikonsumsi oleh manusia dan terjadi bioakumulasi merkuri yang dapat mengakibatkan gangguan kesehatan masyarakat seperti gangguan pada syaraf, kanker dan kematian. Merkuri juga dapat menstimulasi sistem enzimatik yang menyebabkan penurunan adaptasi ikan dan menyebabkan kematian pada ikan. (Wurdiyanto, 2007).

Berdasarkan uraian di atas, maka perlu dilakukan penelitian pada lokasi yang berpotensi tercemar logam berat pada komponen ekosistem di Sungai Tebaung Kabupaten Kapuas Hulu. Hasil penelitan tersebut diharapkan dapat diketahui tingkat pencemaran logam berat pada sungai tersebut. Penelitian ini juga diharapkan dapat diketahui tingkat bioakumulasi pada komponen ekosistem serta status keamanan ikan yang ditangkap dari perairan tersebut.

\section{- Metodologi Penelitian}

Penelitian dilakukan pada bulan juni 2016. Lokasi penelitian dilakukan dibeberapa tempat. Sungai Tebaung Kabupaten Kapuas Hulu untuk pengambilan sampel air permukaan, sedimen sungai, tanaman sekitar sungai, dan ikan. Desa semangut, Desa Sebilit dan Desa Nanga Suruk untuk pengambilan sampel rambut, Laboratorium Baristan Kota Pontianak untuk pengujian sampel. 


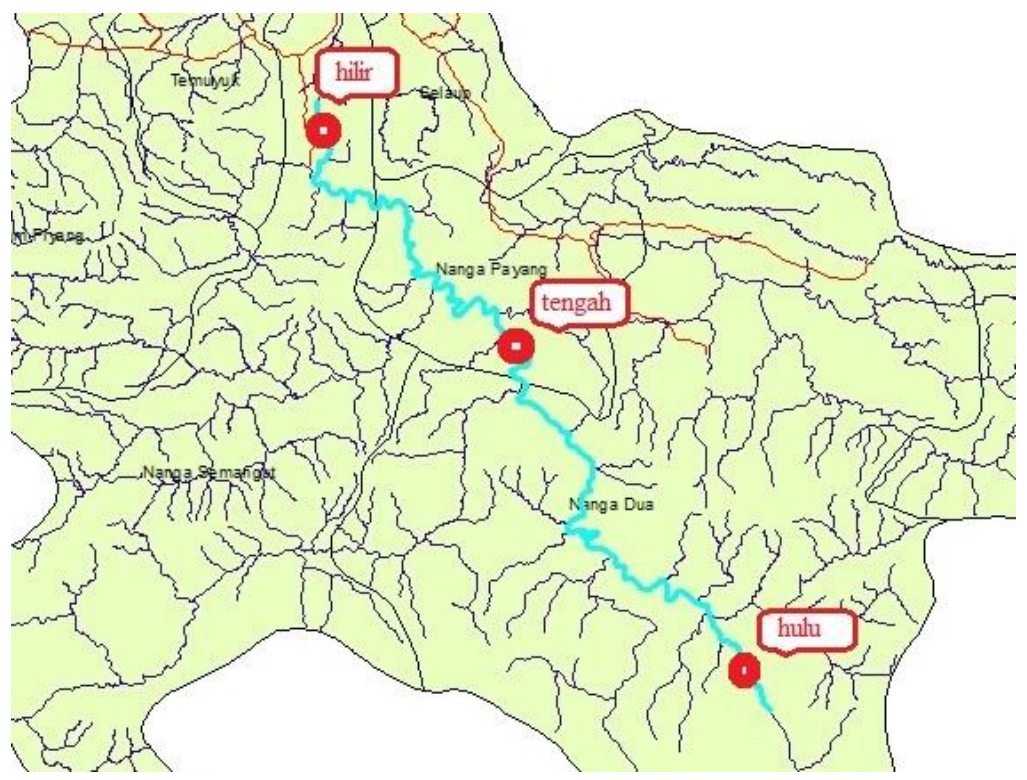

Gambar 1 Peta Kecamatan Bunut Hulu

Alat yang digunakan adalah botol gelap $700 \mathrm{ml}$, tali pengikat, batu pemberat, kertas label, wadah sedimen $1000 \mathrm{ml}$, bambu dengan panjang \pm 2 meter, plastic kedap air, pisau,alumunium foil, gunting. Bahan yang digunakan dalam penelitian ini adalah aquades, alkohol, dan $\mathrm{KMnO}_{4}$.

Pengambilan masing-masing sampel dilakukan pada tiga titik yaitu hulu (titik A) tengah (titik B) dan hilir sungai (titik C) dan dilakukan duplo. Pengambilan sampel yang dilakukan Grab sampling. Teknik pengambilan sampel air permukaan dilakukan dengan mengacu pada SNI 06-2421-1991. Sampel sedimen di ambil dan dimasukkan kedalam botol sebanyak $1000 \mathrm{ml}$, Bungkus menggunakan plastik hitam dan usahakan suhu disekitar sampel stabil, Kemudian sampel dikirim ke laboratorium untuk diuji (Sahrianto, 2015).

Sampel tumbuhan yang dijadikan sampel adalah paku sayur (Diplazium esculentum). Pengambilan sampel berdasarkan tumbuhan yang tampak tumbuh subur dan tidak memperhatikan umur tumbuhan. Tumbuhan yang tumbuh subur tanpa terganggu pertumbuhannya. Sampel tumbuhan diambil pada bagian akar tumbuhan. Akar tersebut dibersih dan dikeringkan kemudian dikemas dalam plastik yang kedap air, Selanjutnya dikirim dan diuji di Laboratorium (Koseregeran, dkk., 2015).

Pengambilan sampel ikan dilakukan dengan menggunakan pancingan ikan yang dipasang di titik sampel dan kemudian dilakukan pemilihan ikan yang tertangkap, yaitu ikan baung. Pengambilan sampel Ikan dilakukan secara random sampling tanpa memperhatikan jenis dan ukuran yang ada dalam populasi. Ikan yang diambil adalah ikan baung. Bagian ikan yang diambil adalah daging, Daging ikan tersebut kemudian diawetkan dengan disimpan pada suhu chilling dalam peti berinsulasi. Selanjutnya dibawa ke laboratorium untuk diuji (Handayani, 2015).

Pengambilan sampel rambut di lakukan di desa yang dialiri Sungai Tebaung. Sampel di ambil pada 3 desa yaitu Desa Semangut, Desa Sebilit dan Nanga Suruk. sampel yang akan diambil berjenis kelamin laki-laki, umur lebih dari 30 tahun, penduduk asli dan mengkonsumsi ikan dari sungai tebaung minimal 2 minggu sekali. Rambut di ambil sekitar 
0.5- 2 gram. Sampel rambut yang telah bersih ditempatkan dalam aluminium foil, ditutup rapat, dikirim ke laboratorium untuk dilakukan uji (Junita, 2013).

Penelitian ini merupakan penelitian deskriptif dengan menjelaskan, sesuatu masalah dengan menggunakan data-data yang diperoleh dari lapangan, data hasil penelitian dan laboratorium serta teori pendukung yang diperoleh dari berbagai literatur. Pengambilaan sampel menggunakan metode eksploratif. Pengambilan sampel dilakukan dengan membagi wilayah menjadi 3 titik sampel, dimana titik sampel ditentukan secara purposive.

\section{- Hasil dan Pembahasan}

\section{a. Kadar Merkuri pada Air Permukaan di Sungai Tebaung}

Hasil pengujian pada sampel air permukaan Sungai Tebaung dapat dilihat pada Tabel 1 berikut ini :

Tabel 1 Konsentrasi Merkuri pada Air Permukaan Sungai Tebaung

\begin{tabular}{|c|c|c|c|c|}
\hline & $\begin{array}{l}\text { Titik Pengambilan } \\
\text { Sampel }\end{array}$ & $\begin{array}{l}\text { Kode } \\
\text { Contoh }\end{array}$ & $\begin{array}{c}\text { Merkuri } \\
\text { Hasil Uji } \\
(\mathrm{mg} / \mathrm{l})\end{array}$ & $\begin{array}{c}\text { Baku Mutu } \\
\text { PP } 82 \text { Tahun } 2001\end{array}$ \\
\hline \multirow[t]{2}{*}{1} & \multirow{2}{*}{ A (Hulu Sungai) } & $\mathrm{A} 1$ & 0,0028 & \multirow{6}{*}{$0,002 \mathrm{mg} / \mathrm{l}$} \\
\hline & & $\mathrm{A} 2$ & 0,0040 & \\
\hline \multirow[t]{2}{*}{2} & \multirow{2}{*}{ B (Tengah Sungai) } & B1 & 0,0032 & \\
\hline & & B2 & 0,0049 & \\
\hline \multirow{2}{*}{3} & \multirow{2}{*}{ C (Hilir Sungai) } & $\mathrm{C} 1$ & 0,0063 & \\
\hline & & $\mathrm{C} 2$ & 0,0057 & \\
\hline
\end{tabular}

Sumber: Hasil Analisis, 2016

Dapat dilihat pada Tabel 1 Konsentrasi merkuri pada air permukaan di hulu Sungai Tebaung merkupakan konsentrasi terendah jika dibandingkan dengan tengah dan hilir sungai. Hal ini kemungkinan dikarenakan di bagian hulu sungai pada saat pengambilan sampel, terdapat aktivitas pertambangan emas yang relatif sedikit dibandingkan dengan bagian tengah dan hilir. Dimana jumlah tambang yang beroperasi pada saat pengambilan sampel sebanyak 6 dan yang tidak beroperasi sebanyak 9 tambang emas. Hal ini kemungkinan dapat menyebabkan merkuri yang ada dibagian hulu sungai mengendap pada sedimen didasar sungai.

Konsentrasi merkuri di tengah sungai lebih tinggi dibandingkan dengan konsentrasi merkuri pada daerah hulu Sungai Tebaung dan lebih rendah dibandingkan merkuri di hilir sungai. Hal ini juga kemungkinan diakibatkan oleh jumlah penambang yang beroperasi di tengah pada saat pengambilan sampel sebanyak 14 tambangan dan hanya 3 yang tidak beroperasi.

Konsentrasi merkuri pada air permukaan di Sungai Tebaung makin meningkat dari hulu, tengah sampai hilir sungai. Hal ini dikarenakan pada bagian hulu, bagian tengah dan bagian hilir tersebar aktivitas pertambangan emas sehingga merkuri dibagian hulu dan tengah kemungkinan akan terbawa oleh aliran sungai sehingga beban merkuri di hilir sungai meningkat. Hal ini juga dapat terjadi akibat proses adveksi-difusi dimana terjadi beberapa 
gerak angkutan materi di dalam badan air atau proses tranfortasi massa dimana polutan merkuri bergerak dari tempat yang lebih tinggi ke tempat yang lebih rendah atau dari hulu ke hilir (Chapra, 1997). Hal ini berarti konsentrasi merkuri pada air permukaan akan semakin meningkat dari hulu hingga hilir Sungai Tebaung.

Hal ini dapat dikatakan bahwa air permukaan di Sungai Tebaung telah tercemaroleh logam merkuri. Sebagaimna kita ketahui, Nilai Ambang Batas (NAB), merupakan suatu keadaan dimana suatu larutan kimia, dalam hal ini Air raksa/merkuri dianggap belum membahayakan bagi kesehatan manusia. Bila dalam air, kadar merkuri sudah melampaui Nilai Ambang Batas, maka air yang diperoleh dari tempat tertentu dinyatakan berbahaya (Rahmawati, 2011).

\section{b. Konsentrasi Merkuri pada Sedimen Sungai Tebaung}

Parameter yang diukur adalah konsentrasi merkuri $(\mathrm{Hg})$. Baku mutu yang digunakan adalah PP No. 18 Tahun 1999 tentang Pengelolaan Limbah Bahan Berbahaya dan Beracun. Kontaminasi merkuri $(\mathrm{Hg})$ dalam sedimen sungai dapat terjadi akibat proses alamiah (pelapukan batuan termineralisasi), proses pengolahan emas secara tradisional (amalgamasi).

Tabel.2 Konsentrasi Merkuri pada Air Sedimen Sungai Tebaung

\begin{tabular}{|c|c|c|c|c|}
\hline No & Nomor Analisis & $\begin{array}{l}\text { Kode } \\
\text { Contoh }\end{array}$ & $\begin{array}{c}\text { Merkuri } \\
\text { Hasil Uji } \\
\text { (mg/l) }\end{array}$ & $\begin{array}{c}\text { Baku Mutu } \\
\text { PP No. } 18 \text { Tahun } \\
1999\end{array}$ \\
\hline \multirow[t]{2}{*}{1} & A (Hulu Sungai) & A1 & 0,1815 & \multirow{6}{*}{$0,01 \mathrm{mg} / \mathrm{l}$} \\
\hline & & $\mathrm{A} 2$ & 0,1185 & \\
\hline \multirow[t]{2}{*}{2} & B (Tengah Sungai) & B1 & 0,0555 & \\
\hline & & B2 & 0,0585 & \\
\hline \multirow[t]{2}{*}{3} & C (Hilir Sungai) & $\mathrm{C} 1$ & 0,0100 & \\
\hline & & $\mathrm{C} 2$ & 0,1240 & \\
\hline
\end{tabular}

Sumber: Hasil Analisis, 2016

Dapat dilihat pada Tabel 2. Hasil pengujian untuk konsentrasi merkuri pada sedimen di hulu sungai didapatkan bahwa pada sampel A1 didapatkan merkuri sebesar 0,1815 mg/l. Hal ini kemungkinan dikarenakan di bagian hulu sungai pada saat pengambilan sampel terdapat aktivitas pertambangan emas yang relatif sedikit dibandingkan dengan bagian tengah dan hilir yang dapat menyebabkan kemungkinan merkuri yang ada dibagian hulu sungai mengendap pada sedimen didasar sungai.

Konsentrasi merkuri pada tengah sungai didapatkan bahwa merkuri pada tertinggi sebesar $0,0585 \mathrm{mg} / \mathrm{l}$. Konsentrasi merkuri di tengah sungai lebih rendah dibandingkan dengan konsentrasi merkuri pada daerah hulu maupun di hilir Sungai dan merupakan konsentrasi merkuri pada sedimen terendah di Sungai Tebaung. Hal ini kemungkinan dikarenakan kadar merkuri pada tumbuhan paku sayur yang tumbuh disekitar atau tengah sungai lebih tinggi dibandingkan dengan kadar merkuri pada tumbuhan paku sayur yang 
tumbuh di sekitar hulu dan hilir sungai. Dengan demikian penurunan konsentrasi merkuri pada sedimen tengah sungai kemungkinan dapat diakibatkan karena merkuri didalam sedimen diserap oleh akar tumbuhan tersebut sehingga konsentrasi pada sedimen di tengah sungai berkurang.

Sedangkan pada hilir sungai didapatkan bahwa konsentrasi merkuri tertinggi sebesar $0,124 \mathrm{mg} / \mathrm{l}$. Hal ini kemungkinan dikarenakan aktivitas pertambangan di hilir sungai relatif banyak sehingga proses sedimentasi juga berbanding lurus dengan aktivitas pertambangan emas.

Berdasarkan hasil pengujian sampel sedimen di Sungai Tebaung dengan pengambilan sampel duplo pada bagian hulu, tengah dan hilir sungai. Konsentrasi merkuri tersebut telah melebihi baku mutu yang ditetapkan Berdasarkan Peraturan Pemerintah No. 18 Tahun 1999 baku mutu zat pencemar dalam limbah untuk parameter merkuri adalah $0,01 \mathrm{Mg} / \mathrm{L}$. Kondisi ini dapat membahayakan lingkungan dan ekosistem didalam perairan karena sedimen merupakan bagian penting dalam ekosistem perairan karena merupakan tempat terjadinya siklus biokimia dan merupakan basis jaring-jaring makanan. Logam berat yang terdapat dalam air akan berpindah ke dalam sedimen jika berikatan dengan materi organik bebas atau materi organik yang melapisi permukaan sedimen, dan penyerapan langsung oleh permukaan partikel sedimen (Arisandi, 2001).

\section{c. Konsentrasi Merkuri pada Ikan di Sungai Tebaung}

Ikan yang dijadikan sampel dalam penelitian ini adalah ikan baung (mystus Nemurus). Ikan baung yang dijadikan sampel ikan karena jumlah spesies ikan baung di Sungai Tebaung masih relatif banyak hal ini dapat dilihat dari masyarakat yang masih sering mendapatkan ikan baung dalam mencari ikan di sungai tersebut. Selain itu ikan baung juga banyak digemari oleh penduduk sekitar sungai karena rasanya yang lezat. Jadi diasumsikan bahwa paparan merkuri pada manusia dapat diakibatkan dari mengkonsumsi ikan baung yang berada di Sungai Tebaung. Selain itu ikan baung merupakan golongan omnivora (pemakan segala) sehingga bioakumulasi merkuri pada ikan baung dapat dilihat dari pola makan dari ikan baung. Sampel ikan yang digunakan dalam penelitian ini adalah ikan baung yang tertangkap di setiap titik di sungai tersebut.

Tabel 3 Konsentrasi Merkuri pada Ikan di Sungai Tebaung

\begin{tabular}{|c|c|c|c|c|}
\hline No & Titik Sampel & $\begin{array}{c}\text { Kode } \\
\text { Contoh }\end{array}$ & $\begin{array}{l}\text { Merkuri } \\
\text { Hasil Uji } \\
\text { (mg/kg) }\end{array}$ & $\begin{array}{l}\text { Baku Mutu } \\
\text { WHO } 2004\end{array}$ \\
\hline \multirow{2}{*}{1} & \multirow{2}{*}{ A (Hulu Sungai) } & $\mathrm{A} 1$ & $<0,004$ & \multirow{6}{*}{$0,5 \mathrm{mg} / \mathrm{kg}$} \\
\hline & & $\mathrm{A} 2$ & $<0,004$ & \\
\hline \multirow{2}{*}{2} & \multirow{2}{*}{ B (Tengah Sungai) } & B1 & $<0,004$ & \\
\hline & & B2 & $<0,004$ & \\
\hline \multirow{2}{*}{3} & \multirow{2}{*}{ C (Hilir Sungai) } & $\mathrm{C} 1$ & 0,0047 & \\
\hline & & $\mathrm{C} 2$ & 0,0051 & \\
\hline
\end{tabular}

Sumber: Hasil Analisis, 2016

Hasil pengujian didapatkan bahwa pada sampel A1 dan A2 memiliki konsentrasi merkrui yang sama. Dimana konsentrasi pada ikan yaitu $<0,004 \mathrm{mg} / \mathrm{kg}$. pada sampel B1 dan 
B2 pada ikan juga mengandung konsentrasi yang sama yaitu $<0,004 \mathrm{mg} / \mathrm{kg}$. Hal ini kemungkinan disebabkan karena pada hulu dan tengah sungai pencemaran merkuri di lingkungan perairan masih relatif rendah bila dibandingkan dengan hilir sungai.

Sedangkan hasil pengujian pada hilir sungai didapatkan konsentrasi merkuri tertinggi C2 sebesar 0,0051 mg/kg. Hal ini dikarenakan pada hilir sungai konsentrasi merkuri padaa air permukaan dan sedimen cenderung lebih tinggi dibandingkan dengan titik lain sehingga resiko bioakumulasi merkuri pada ikan juga lebih besar.

Hasil pengujian ini masih dibawah standar baku mutu yang ditetapkan oleh 2004 dan SNI 7387-2009 yaitu 0,5 mg/kg. Artinya ikan baung masih aman untuk dikonsumsi masyarakat sekitar Sungai Tebaung karena pada tiga titik sampel ikan masih dibawah baku mutu. Perlu diketahui bahwa konsentrasi merkuri di titik $C$ dapat terus meningkat apabila proses bioakumulasi merkuri pada ikan terus berjalan akibat pencemaran merkuri pada Sungai Tebaung.

\section{d. Konsentrasi Merkuri pada Tumbuhan di Sekitar Sungai Tebaung}

Sampel tumbuhan yang dijadikan sampel adalah paku sayur (Diplazium esculentum) (Widyati, 2011).

Tabel 4 Konsentrasi Merkuri pada Paku Sayur di Sekitar Sungai Tebaung

\begin{tabular}{ccccc}
\hline No & Nomor Analisis & $\begin{array}{c}\text { Kode } \\
\text { Contoh }\end{array}$ & $\begin{array}{c}\text { Merkuri } \\
\text { Hasil uji } \\
\mathbf{( m g / k g )}\end{array}$ & $\begin{array}{c}\text { Baku Mutu } \\
\text { SNI 7383-2009 }\end{array}$ \\
\hline \multirow{2}{*}{1} & A (Hulu Sungai) & A1 & 0,0096 & \\
& & A2 & 0,0038 & \\
2 & B (Tengah Sungai) & B1 & 0,1380 & $0,003 \mathrm{mg} / \mathrm{kg}$ \\
& & B2 & 0,0079 & \\
3 & C (Hilir Sungai) & C1 & 0,0086 & \\
& & C2 & 0,0193 & \\
\hline
\end{tabular}

Sumber: Hasil Analisis, 2016

Hasil pengujian untuk konsentrasi merkuri pada akar tumbuhan paku sayur di hulu sungai didapatkan sebesar $0,0096 \mathrm{mg} / \mathrm{kg}$. Konsentrasi merkuri pada akar paku sayur di tengah sungai didapatkan bahwa merkuri pada tertinggi sebesar 0,138 mg/kg. Konsentrasi merkuri pada tumbuhan paku sayur di titik ini merupakan konsentrasi tertinggi pada tumbuhan paku sayur di Sungai Tebaung yang diuji. Sedangkan pada hilir sungai didapatkan bahwa konsentrasi merkuri tertinggi sebesar $0,0193 \mathrm{mg} / \mathrm{kg}$.

Berdasarkan hasil pengujian sampel akar tumbuhan paku disekitar di Sungai Tebaung dengan pengambilan sampel duplo pada bagian hulu, tengah dan hilir sungai. Konsentrasi merkuri tersebut telah melebihi baku mutu yang ditetapkan oleh SNI 7387-2009 tentang batas maksimum cemaran logam berat dalam pangan yaitu $0,003 \mathrm{mg} / \mathrm{kg}$. 


\section{e. Konsentrasi Merkuri pada Rambut Manusia}

Tabel 5 Konsentrasi Merkuri pada Rambut Manusia

\begin{tabular}{ccccc}
\hline No & Nomor Analisis & $\begin{array}{c}\text { Kode } \\
\text { Contoh }\end{array}$ & $\begin{array}{c}\text { Merkuri } \\
\text { Hasil uji (mg/kg) }\end{array}$ & $\begin{array}{c}\text { Baku Mutu } \\
\text { WHO 1990 }\end{array}$ \\
\hline \multirow{2}{*}{1} & \multirow{2}{*}{ Titik A (Desa Semangut) } & A1 & 0,0001 & \\
& & A2 & 0,0500 & \\
2 & \multirow{2}{*}{ Titik B (Desa Sebilit) } & B1 & 0,0001 & \multirow{2}{*}{$1 \mathrm{mg} / \mathrm{kg}$} \\
& & B2 & 0,0670 & \\
3 & \multirow{2}{*}{ Titik C (Desa Semangut) } & C1 & 0,8130 & \\
& & C2 & 0,2290 & \\
\hline
\end{tabular}

Sumber: Hasil Analisis, 2016

Hasil pengujian untuk konsentrasi merkuri pada rambut di Desa semangut yang terletak disekitar hulu sungai didapatkan bahwa konsentrasi tertinggi rambut manusia Desa Semangut sebesar $0,05 \mathrm{mg} / \mathrm{kg}$. Desa Nanga Semangut merupakan konsentrasi merkuri terendah pada rambut manusia. Konsentrasi merkuri pada rambut di Desa Sebilit yang berada disekitar tengah sungai didapatkan bahwa merkuri pada konsentrasi merkuri tertinggi sebesar $0,067 \mathrm{mg} / \mathrm{kg}$. Desa Sebilit mengandung konsentrasi merkuri sedikit lebih tinggi dibandingkan Desa Semangut.

Sedangkan pada Desa Nanga Suruk yang berada disekitar hilir sungai didapatkan bahwa konsentrasi merkuri tertinggi sebesar $0,813 \mathrm{mg} / \mathrm{kg}$ Pada titik $\mathrm{C}$ atau pada Desa Nanga Suruk konsentrasi merkuri mengalami kenaikan yang cukup signifikan. Hal ini kemungkinan disebabkan karena kadar merkuri di titik $\mathrm{C}$ atau hilir sungai lebih tinggi dari titik lain. Dimana masyarakat di Desa Nanga Suruk terletak di daerah hilir sungai. Selain itu kadar merkuri pada air permukaan di hilir sungai juga lebih tinggi dari pada hulu dan tengah sungai. Hal ini juga mempengaruhi kadar merkuri dalam rambut manusia di Desa Nanga Suruk karena masyarakat sekitar menggunakan air sungai untuk kegiatan MCK sehingga kemungkinan merkuri juga diserap rambut dari kegiatan MCK tersebut.

Berdasarkan hasil pengujian sampel rambut manusia pada 3 desa yang dialiri Sungai Tebaung dengan pengambilan sampel duplo pada bagian hulu, tengah dan hilir sungai. Konsentrasi merkuri tersebut masih dibawah baku mutu yang ditetapkam oleh WHO 1990 yaitu $1 \mathrm{mg} / \mathrm{kg}$. Namun konsentrasi merkuri di titik $C$ atau di Desa Nanga Suruk sudah mengkhawatirkan

\section{f. Persebaran Merkuri Pada Komponen Ekosistem Di Sepanjang Sungai Tebaung}

Konsentrasi merkuri pada ikan menjadi rendah hal ini disebabkan oleh beberapa faktor. Konsentasi merkuri pada ikan dalam bentuk $\mathrm{CH}_{3} \mathrm{Hg}^{+}$dan diakumulasi oleh insang dan didistribusikan oleh darah keseluruh tubuh untuk diakumulasi dan diekskresi keluar tubuh. Melalui jalur pakan Hg2+ harus dicerna terlebih dahulu oleh system pencernaan sehingga sebagian besar terakumulasi di dalam usus . Kemudian terdistribusi pada organ ditentukan oleh sumber paparan (air dan pakan) dan kuantitas paparan (Havelkova et al, 2008). Paparan $\mathrm{CH}_{3} \mathrm{Hg}^{+}$melalui jalur air mengakibatkan 58,65\% terakumulasi di dalam daging, $4,69 \%$ di dalam insang, $19,26 \%$ di dalam kepala dan $17,4 \%$ di dalam usus (Suseno, 2011).. 
Namun pada penelitian ini organ yang diambil adalah bagian daging Ikan Baung (Mystus Nemurus) sehingga konsentrasi merkuri sangat rendah. Selain itu Ikan Baung yang digunakan sebagai sampel belum mencapai umur dan bobot maksimum, sehingga konsentrasi merkuri pada ikan relatif rendah.

Konsentrasi merkrui pada rambut manusia juga mengalami penurunan. Hal ini disebabkan akumulasi merkuri pada manusia memakan waktu yang lama untuk terakumulasi ditubuhnya. Hal yang sama juga menjadi faktor besarnya kadar merkuri didalam rambut manusia adalah, jenis kelamin, lama tinggal dengan daerah tercemar logam, umur, jenis panganan yang dimakan. Ikan yang dimakan manusia biasanya bagian daging, namun pada daging merkuri hanya sebesar $4,69 \%$. Sedangkan insang dan usus yang merupakan persentasi tertinggi distribusi merkuri dalam organ ikan tidak dikonsumsi atau dibuang.

\section{- Kesimpulan}

Berdasarkan penelitian yang telah dilakukan dapat diambil kesimpulan sebagai berikut:

a. Konsentrasi merkuri pada air permukaan di bagian hulu sungai sebesar 0,004 mg/l , di tengah sungai dan sebesar $0,0049 \mathrm{mg} / \mathrm{l}$ dan hilir Sungai $0,0063 \mathrm{mg} / \mathrm{l}$ telah melebihi baku mutu PP 82 Tahun 2001 untuk kelas 2 yaitu 0,002 mg/l. Sedangkan konsentrasi merkuri pada sedimen di bagian hulu sungai sebesar $0,1815 \mathrm{mg} / \mathrm{l}$, tengah sungai sebesar $0,0585 \mathrm{mg} / \mathrm{l}$ dan hilir sungai sebesar $0,124 \mathrm{mg} / \mathrm{l}$ telah melebihi baku mutu PP 18 tahun 1999 yaitu 0,01 mg/l. Konsentrasi merkuri pada paku sayur yang tumbuh di sekitar hulu sebesar $0,0096 \mathrm{mg} / / \mathrm{kg}$, di bagian tengah sungai sebesar $0,0124 \mathrm{mg} / \mathrm{kg}$ dan hilir sungai sebesar 0,0193 mg/kg juga telah melebihi baku mutu SNI 7383-2009 yaitu $0,003 \mathrm{mg} / \mathrm{kg}$. Konsentrasi merkuri pada ikan di hulu sungai $<0,004 \mathrm{mg} / \mathrm{kg}$, di hilir sungai $<0,004 \mathrm{mg} / \mathrm{kg}$ dan di hilir sungai sebesar $0,0047 \mathrm{mg} / \mathrm{kg}$ masih dibawah baku mutu yang di tetapkan oleh WHO 2004 sebesar $0,5 \mathrm{mg} / \mathrm{kg}$.

b. Akumulasi merkuri pada rambut manusia di Desa Semangut sebesar 0,05 mg/kg, Desa Sebilit sebesar 0,067 mg/kg dan Desa Nanga Suruk sebesar 0,813 mg/kg .

c. Dari hasil analisis menunjukan adanya sebaran merkuri pada komponen ekosistem di Sungai Tebaung yang ditandai dengan adanya akumulasi merkuri pada ikan dan rambut manusia serta konsentrasi merkuri semakin meningkat pada bagian hilir Sungai Tebaung.

\section{- Ucapan Terimakasih}

Dengan selesainya penelitian ini saya mengucapkan terima kasih yang sebesarbesarnya kepada Allah Swt, kedua orang tua, kedua dosen pembimbing yaitu Ibu Dian Rahayu Jati, S.T, M.Si dan Ibu Ulli Kadaria, S.T, M.T serta kepada teman-teman Teknik Lingkungan 2012 dan semua orang yang telah berperan dalam membantu penelitian yang tidak dapat di ucapkan satu persatu. Harapan saya penelitian ini dapat bermanfaat bagi semua dan dapat dipergunakan sebagaimana mestinya. 


\section{- $\quad$ Daftar Pustaka}

Arisandi, 2001, "Mangrove Jenis Api-api (Avicennia marina) Alternatif Pengendalian Logam Berat Pesisir", URL:http://www.terranet.com. [2 September 2016)

Chapra, 1997, "Surface Water Quality Modeling", Mc. Graw Hill Companies, Inc. , New York. Handayani. R., I 2015, Akumulasi Logam Berat Kromium (Cr) Pada Daging Ikan Nila Merah (Oreochromis Sp) Dalam Karamba Jaring Apung (Kja) di Sungai Winongo Yogyakarta. Universitas Negeri Semarang. Semarang.

Ikingura, J.P. \& H. Akagi. 1999. Methylmercury production and distribution in aquatic systems. Science of Total Environment J

. 23(4): 109-118.

Kosegeran1, A.I dkk., 2015, Kandungan Merkuri pada Tumbuhan Paku (Diplazium Accedens Blume) di Daerah Tambang Emas Tatelu Talawaan, Kabupaten Minahasa Utara. Universitas Sam Ratulangi Manado. Manado.

Sarjono, A., 2009. Analisis Kandungan Logam Berat Cd, Pb, dan Hg Pada Air dan Sedimen di Perairan Kamal Muara, Jakarta Utara, Skripsi, Institut Pertanian Bogor, Bogor.

Sorensen., 1991. Basic Coastal Engineering. U.S. Army Coastal Engineering Research Center Virginia.

Wurdiyanto, G., 2007. Merkuri, Bahayanya dan Pengukurannya. Buletin Alara 9, $(1,2)$. 